7. Twenty-Year Mutual Assistance Agreement Between the United Kingdom and the Union of Soviet Socialist Republics : May 26, 1942. URL: https://avalon.law.yale.edu/wwii/brsov42.asp (дата обращения 17.01.2021)

8. Roosevelt and Churchill, their secret wartime correspondence. N.Y., 1975. P. 151, 153-155.

9. Roosevelt E. As He saw it. N.Y., 1946. P. 76-77.

10. Иванян Э. А. Белый дом: президенты и политика. М., 1979. С. 144.

11. Жаронкина Е. А. Американская позиция по германскому вопросу в рамках сотрудничества стран антигитлеровской коалиции // Вестник Кемеровского государственного университета. 2014. № 3 (59). T. 2. С. 287-292.

12. СССР и германский вопрос. 1941-1949: Документы из Архива внешней политики РФ: В 2-х т. М., 2000.

13. Сталин И.В. Сочинения: Т. 1-18/ Т. 15. М.1997. С. 93-98.

14. The Moscow Conference; October 1943. URL: https://avalon.law.yale.edu/wwii/moscow.asp (дата обращения 17.01.2021).

15. Советский Союз на международных конференциях периода Великой Отечественной войны, 19411945 гг.: Сборник документов в 2-х т. М., 1984 / Т. 1. Московская конференция министров иностранных дел СССР, США и Великобритании (19-30 окт. 1943 г.). Т. 1. С.170, 336-337.

16. Советский Союз на международных конференциях периода Великой Отечественной войны, 19411945 гг.: Сборник документов в 2-х т. М., 1984 / Т. 2. Тегеранская конференция руководителей трех союзных держав - СССР, США и Великобритании (28 ноября - 1 дек. 1943 г.). М., 1978. С. 165 167.

17. Foreign Relations of the United States, Conference at Quebec, 1944. Washington, 1972. P. 86.

18. Morgenthau H. Germany is our Problem. N.Y., 1945. P.83.

19. Голль Ш. де. Военные мемуары: Спасение 1944-1946/ пер. с франц. М.,2004. С. 73-74, 82-83.

\title{
Середа Н.В.
}

\section{«Свои» и «чужие» в городском пространстве России в XVII - XVIII вв.}

Тверской государственный университет (Россия, Тверь)

doi: 10.18411/scienceconf-03-2021-61

idsp: scienceconf-03-2021-61

\section{Аннотация}

Цель настоящей статьи заключается в том, чтобы показать основные этапы в изменении структуры городского населения и представлений о ней историков и правоведов.

Ключевые слова: посадские люди, беломестцы, разночинцы, граждане городов, купцы мещане, общество купцов и мещан, обывательские книги, гильдии.

Разработка данной проблемы при всей современности ее звучания началась еще в середине XIX в., когда правоведы (Л.Д., Плошинский А,П. Пригара, И.И. Дитятин и др.) изучали структуру населения городов России, основываясь на текстах Полного собрания законов Российской империи. В своих сочинениях они противопоставляли служилое и тяглое население, выделяли в рамках каждой из этих основных групп более мелкие, отмечали различия в правах и обязанностях, подведомственность различным приказам.

В 1903 г. появилась работа А.А. Кизеветтера где автор, опираясь на огромное количество делопроизводственных источников по истории городов Подмосковья, показал жизнь посадской общины второй и третьей четверти XVIII в. Этот ученый, вопервых, отождествлял состав посадской общины и податное население городов, выделял в его составе лишь две основные группы горожан: зажиточное купечество и ремесленников. Пытаясь объяснить случаи противоречий, разногласий, а подчас и прямых столкновений между горожанами, он апеллировал к идеям борьбы между богатыми и бедными, т.е. в основу деления на «своих» и «чужих» в структуре городского населения Кизеветтер по сути кладет принцип зажиточности.

Однако в трудах Н.Д. Чечулина, А.С. Лаппо-Данилевского, М.М. Богословского, С.К. Богоявленского П.П. Смирнова и других ученых конца XIX - начала XX в. 
структура городского населения выглядит несколько по иному. Исследуя писцовые и переписные книги, делопроизводственные материалы центральных учреждений, они убедительно подтверждали правоту представлений правоведов о более сложной структуре населения городов России.

В советский период при характеристике городского населения применительно к XVII в. сложилась устойчивая терминологическая оппозиция «посадские беломестцы», которую можно встретить и фундаментальных изданиях по истории страны и в учебной литературе. К числу беломестцев относили как служилое население городов, так и живущих в городах крестьян. Беломестцы считались привилегированным городским населением, так как, по мнению историков советского периода, не платили налоги за занятия торговлей и промыслами и не исполняли повинности, лежавшие на членах посадской общины. Беломестцы чаще всего селились особыми слободами, имели свои органы самоуправления и подчинялись разным приказам: пушкари - Пушкарскому, каменщика - Приказу Каменных дел, дворяне Разрядному приказу. Все эти самоуправляющиеся территориально-профессиональные образования и их население были чужими друг-другу и членам посадской общины города.

Историки единодушны в мнении, что тенденция на унификацию платежей торгово-ремесленного населения городов проявилась еще в ходе работы над Судебником 1649 г, продолжилась 1704 г., когда вышел менее известный указ, по которому все мастеровые и торговые люди должны были пройти регистрацию у воевод и платить деньги (от 2 алтын до 2 гривен в год) за право вести свою деятельность. Одновременно в стране стали проводить регистрацию записных ремесленников и перепись корпоративного имущества.

Внимание историков к проблемам демографии активизировало исследование городского населения и его структуры. Было установлено важное значение для консолидации городского населения проведения первой переписи и введения магистратского устройства. Авторы отмечали, что в ходе податной реформы Петра I пушкари, стрельцы и другие категории городского населения, иногда даже дворяне, были положены в подушный оклад по городу, где проживали. При этом традиция отождествлять состав посадской общины города и положенное в оклад по городу население оказалась очень живучей, М,О. Акишин, например, саму перепись называл «посадским строением». Введенное Петром I деление горожан на гильдии не осталось незамеченным и в составе горожан применительно к XVIIIв. ученые стали выделять гильдейское «купечество», противопоставляя его остальным горожанам. Имущественный принцип разделения горожан сосуществовал с делением их на податное и неподатное городское население. При этом податное население по умолчанию отождествлялось с составом посадской общины.

Активное изучение общественной борьбы в России ввело в оборот термин «разночинцы» для обозначения неподатной группы городских жителей. И.Б. Сидорова установила, что в XVIIIв. разночинцы не исполняли всего многообразия обязанностей, возложенных на членов посадской общины. В частности, они были избавлены от тяжелейшей, требующей долгих отлучек из города службы при сборе косвенных налогов В.Р. Тарловская убедительно показала неравноправное положение торговых крестьян среди горожан.

Эти наблюдения оказали серьезное влияние на эволюцию представлений о структуре городского населения и позволили автору данной статьи высказать мнение, что финансовая реформа Петра создала в городах принципиально новую корпорацию городских жителей - лично свободных плательщиков подушной подати. Регламент Главного магистрата (1721) и Инструкция магистратам (1724) называют этих горожан « регулярными гражданами». Новой формой организации этих граждан должны были стать гильдии, они существовали в городах наряду с традиционными сотнями, 
слободами и посадской общиной. Далеко не все податное население городов входило в состав посадской общины. Параллельное существование новой (гильдейской) и традиционной организации городского населения обеспечило постепенный переход к другой структуре городского населения, для ее обозначения чаще всего используют терминологическую оппозицию «податное - неподатное население». Очень часто, особенно применительно к XIX в. как синоним понятия «неподатное население» в литературе используют термин « разночинцы».

Исследование делопроизводственной документации городов Тверской губернии конца XVIII в. свидетельствует, как сами горожане представляли себе структуру городского населения. В большинстве городов выделяли группу горожан, составлявших «общество купцов и мещан»- «граждан» данного города и группу лиц, в это общество не входивших. В число «граждан» входили лишь люди, внесенные в ревизскую сказку по данному городу и платившие здесь подушную подать. Известны случаи, когда люди проживали в городе, имели в нем дом, были записаны в обывательскую книгу, цехи или гильдии и при этом не являлись членами городского «общества купцов и мещан». Запись в цехи или городовую обывательскую книгу в качестве «настоящего городового обывателя» или иногороднего купца сами по себе не обеспечивали принятия в городское общество. «Чужими» являлись приезжавшие на время жители других городов и крестьяне, особенно в том случае, если они пытались заниматься предпринимательством, не вступая ни в цехи ни в гильдии города, где они поселились. Оппозиция «мещанство - купечество», на мой взгляд, отнюдь не являлась главной, хотя и существовала, конечно. В любом городе местные купцы для мещан этого города, были «своими», в то время как мещанин любого другого города Российской империи, поселившийся здесь, был для них чужаком, и в состав городского общества мог быть включен лишь в ходе очередной ревизии. Лишь после этого он становился своим и то не всегда. Есть основания предполагать, что в губернском городе Твери «общество купцов и мещан» отождествлялось идеологом этого города, Д.И. Кармановым, с категорией старожилов города и составом ранее существовавшей посадской общины. К концу XVIII в. после упрощения, а затем и ликвидации системы косвенных налогов исчезла и повинность по их сбору. Именно это и привело к нивелировке в правах и обязанностях податных горожан и постепенному забвению понятий «посадская община» и «посадские люди». Территориальные корпорации - «общества купцов и мещан» того или иного города продолжали существовать и в ХІХв., до ликвидации подушной подати. При этом в городах еще со времени правления Екатерины II происходило формирование «территориального единства городских земель», которое, по мнению Д.Я. Резуна, в свою очередь «являлось географической основой социального процесса - образования городского общества как совокупности лиц различных сословий, имеющих оседлость и недвижимость в пределах города».

$$
* * *
$$

1. Акишин, М.О. І ревизия и посадское строение в Сибири // Россия и Восток. Тезисы международной конференции. Ярославль, 1995. Вып.2, ч.2. С.164-167.

2. Анисимов, Е.В. Податная реформа Петра I: Введение подушной подати в России 1719-1728 гг. Л., 1982.

3. Богословский, М.M. Состав московского населения в XVI - XVII в. // Москва в ее прошлом и настоящем. Т. 3 . М., 1910. С. $44-55$.

4. Богоявленский, С.К. Управление Москвой в XVI - XVII веках //Москва в ее прошлом и настоящем. М., 1910. Вып. 3. С. $81-86$;

5. Богоявленский С.К. Состав Московского слободского схода // Сборник статей по русской истории, посвященных С.Ф. Платонову. Петербург, 1922. С. 322-329;

6. Булгаков, М.Б. Тверские «записные» каменщики и кирпичники в первой половине XVII в.// Города европейской России конца XV - первой половины XIX века Ч. II. Тверь, 2002. с. 139 - 149.

7. Выпись из тверских писцовых книг Потапа Нарбекова и подьячего Богдана Фадеева 1626 г. Тверь, 1901 
8. Голикова, Н.Б. К вопросу о составе русского купечества во второй половине XVII - первой четверти XVIII в. // Русский город. М, 1980. - Вып. 3. С. 37-65.

9. $-215 \mathrm{c}$.

10. Дитятин, И.И. Из истории “ Жалованных грамот” дворянству и городам 1785 года // Дитятин И.И. Статьи по истории русского права. СПб, 1896.

11. Дитятин, И. И. Устройство и управление городов России.Т.1: Города России в XVIII в. СПб., 1875

12. Ефименко, Т.П. Очерк организации городских ремесел в Московском государстве XVI и XVII вв. // Журнал министерства юстиции. СПб., 1914. № 4. С. 114-162.

13. Индова, Е.И. Крестьяне и город Центральной России в XVIII веке // Проблемы социальноэкономической истории феодальной России. М.. 1984. С. 171-180;

14. Кизеветтер, А.А. Посадская община России в XVIII столетии. М., 1903 г .

15. ; Козлова, Н.В. Абсолютизм и русское купечество в XVIII в. (20-е - начало 60-х годов). М., 1999;

16. Лаппо-Данилевский, А.С. Организация прямого обложения в Московском государстве со времен Смуты до эпохи преобразований. СПб., 1890. В 2011 г. вышло 2-е издание этой работы (М., 2011);

17. Новиков, М.А. Рекрутская повинность как социальное явление в Ржевском уезде Тверской губернии во второй половине XVIII века. //Проблемы социально-политической истории России.сб. науч. трудов.Вып. 4 Тверь. 2004. С.77 - 90.

18. Панкратова, А.М. Формирование пролетариата в России (XVII - XVIII вв.) М., 1963.

19. Плошинский, Л.Д. Городское или среднее состояние русского народа в его историческом развитии от начала Руси до новейших времен. СПб, 1852.

20. Пригара, А.П. Опыт истории состояния городских обывателлей в Восточной России. Ч.1.: Происхождение состояния городских обывателей в России и организация его при Петре Великом / А.П. Пригара. - СПб., 1868. - 220 с.

21. Резун, Д.Я. Современная урбанистика и сибирское городоведение XVIII - первая половина XIX в. // Источниковедение и историография городов Сибири конца XVI - первой половины XIX в. Новосибирск, 1987.

22. Савельев, А. Столетие городского самоуправления в Нижнем Новгороде. 1785-1885. Н. Новгород, 1885

23. Середа, Н.В. Документационное обеспечение и организация сбора городских налогов в XVIII в. //Государственное управление: история и современность. Международная научная конференция. Москва. 29-30 мая 1997 г. М., 1998. С. 101-104.

24. Середа, Н.В. Городское гражданство России в последней четверти XVIII в. // Россия в IX - XX векаX. Проблемы истории, историографии и источниковедения. М., 1999. С. 422-424.

25. Середа, Н.В. Купечество в структуре населения городов России // Торговля, купечество и таможенное дело в России в XVI - XIX вв. Сборник материалов Второй международной научной конференции (Курск, 2009 г.). Курск, 2009. С. 174-178.

26. Середа, Н.В. Структура тяглого населения городов Европейской России в отечественной историографии //Историографические чтения памяти профессора Виктора Александровича Муравьева:сб. ст.: В 2 т.:Рос. гос. гуманитар. ун-т, Науч.-пед. школа источниковедения - сайт Источниковедение.ru. - М. : РГГУ, 2013. Т. 2. С. 66-100. .

27. Сидорова, И. Б. Положение разночинцев в русском обществе (XVIII-первая половина XIX в.). Автореф. дис... канд... истор. наук. Казань, 1982.

28. Смирнов, Д.Н. Очерки жизни и быта нижегородцев XVII - XVIII веков. Изд.2-е. Горький, 1978

29. Смирнов, П.П. Города Московского государства в первой половине XVII века. Киев, 1917. ВЫп.1: Формы землевладения.

30. Смирнов, П.П. Посадские люди и их классовая борьба до середины XVII в. Т. 1, 2. Л., 1947.

31. Сперанский, А.Н. Очерки по истории Приказа каменных дел. М., 1930.

32. Тарловская, В.Р. Из истории городской реформы в России конца XVII-начала XVIII в. // Государственные учреждения России XVI - XVIII в. М., 1991. С. 102.

33. Тарловская, В.Р. Ростовщические операции московских кулпцов и торговых крестьян в начале XVIII в. //Вестник Моск. ун-та. Сер.8. История. 1977. № 3. С. 44-55;

34. Тарловская, В.Р.. Торговые крестьяне как категория городского населения (конец XVII - начало XVIII в.) // Русский город. М., 1986. Вып. 8. С. 115-131.

35. Чечулин Н.Д. Города Московского государства. М.. 1889;

36. Чечулин Н. Несколько слов о «старых служеб служилых людях» в XVIII в.// Сборник в честь Матвея Кузмича Любавского. Пг., 1917. С. 32-39.

37. Юркин, И.Н. Выборные службы в системе управления Оружейной слободой Тулы в первой трети XVIII столетия // Управление городами: история и современность. Тверь, 2001. С. 129-141.

38. Юрьев, В.П. Состояние города Вятки в царствование императрицы Екатерины II-й: очерк из истории городского общественного управления. Вятка, 1885. 